\title{
Comparison of Erythrocyte Sedimentation Rate Results of Test-1 and Automatic Westergren Device with Reference Westergren Method
}

\author{
Referans Westergren Metodu ile Test-1 ve Otomatik Westergren Cihazı Eritrosit Sedimentasyon Hızı \\ Sonuçlarının Karşılaştırılması
}

\section{Çiğdem Sönmez ${ }^{1}$, Gülcan Güntaş ${ }^{1}$, Ayşegül Öztürk Kaymak ${ }^{1}$, Nedim Akkaya ${ }^{1}$, Kadir Okhan Akin ${ }^{2}$}

${ }^{1}$ Dr. Abdurahman. Yurtaslan Oncology Education and Research Hospital, Central Laboratory, Ankara, Turkey

${ }^{2}$ Atatürk Education and Research Hospital, Department of Biochemistry, Ankara, Turkey.

\section{ABSTRACT}

Aim: International Council of Standardization in Hematology (ICSH) suggests Westergren method as a reference method in erythrocyte sedimentation rate (ESR) measurement. There are lots of modified methods and devices which use different sample types recently. We investigated to compare the devices which are present in our hospital; Test-1 device that uses samples with EDTA and the device which is compatible with automatic Westergren method that uses infrared technique and studies with citrated samples; by using the reference method that is Westergren method.

Method: From a total of 80 patients for ESR test, blood samples were taken at the same time into the tubes with $\mathrm{K}_{2}$ EDTA and sodium citrate on 7 separate days; and after these blood samples arrived at our laboratory in 2 hours, they were studied with reference Westergren method and in Test-1 and automatic Westergren devices. These two methods were statistically compared with each other and also with the reference method by using concordance correlation coefficient and Passing-Bablok regression analysis method.

Results: ESR result values were dispersed in the interval of 1-78 $\mathrm{mm} / \mathrm{hour}$, while $R^{2}$ values in the correlation of reference Westergren method with Test1 and automatic Westergren devices were found as 0,86 (\%95 $\mathrm{Cl} 0,801$ to $0,913)$ and $0,978(\% 95 \mathrm{Cl} 0,967$ to 0,985$)$, respectively. $\mathrm{R}^{2}$ value in the correlation between two devices was found as 0,898 (\%95 0,846 to 0,933). In the Passing Bablok analysis, in the regression analysis of devices with reference method, intercept for Test-1 device was found as $-0,5$ (\%95 Cl$2,42-0)$ and the slope was 1,09 (\%95 Cl 1-1,21) ( $y=-0,5+1,09 x)$. Intercept for automatic Westergren device was found as $-0,25$ (\%95 Cl-1,26-0) and the slope was 1,03 (\%95 Cl 1-1,08) $(y=0,25+1,03 x)$. Intercept for comparison of these two systems was found as $-0,14(\% 95 \mathrm{Cl}-1,01-0)$ and the slope was 1,02 (\%95 Cl 1-1,17) $(y=-0,14+1,02 x)$. There was no significant difference between the groups with student t-test $(p>0,05)$.

Conclusion: Test-1 method and automated Westergren method devices can be used reliably in the ESR measurement in routine laboratory as compared with reference Westergren method. At high ESR values Test- 1 device has deviations from the reference method. We suggest that the evaluation of results of high sedimentation values be made carefully and for high ESR values comprehensive studies be supported by further research.

Key Words: Erythrocyte Sedimentation Rate, Reference Westergren method Test-1 Method

\section{ÖZET}

Amaç: International Council of Standardization in Heamatology (ICSH) eritrosit sedimentasyon hızı (ESR) ölçümünde referens metod olarak Westergren yöntemini önerse de günümüzde farklı numune türleri kullanan, birçok modifiye yöntem ve cihaz bulunmaktadır. Biz de hastanemizde bulunan EDTA'lı örnek kullanan Test-1 cihazı ile sitratlı örnek kullanan infrared tekniği ile çalışan otomatik westergren metodu ile uyumlu cihazı referans yöntem Westergren metodu ile karşılaştırmayı amaçladık.

Yöntem: ESR ve hemogram testi için $\mathrm{K}_{2}$ EDTA ve sodyum sitratlı tüplere eş zamanlı 7 ayrı günde toplamda 80 hastadan alınan kan örnekleri 2 saat içinde laboratuvarımıza ulaştıktan sonra Test-1 ve otomatik Westergren cihazlarında ve referans Westergren metodu ile çalışıldı. Her iki yöntem birbirleri ile ve referans metod ile istatistiksel olarak concordance correlation coefficient ve Passing-Bablok regresyon analiz yöntemi ile karşılaştırıldı.

Bulgular: ESR sonucu 1-78 mm/saat aralığında dağılan değerlerde Test-1 ve otomatik Westergren cihazlarının referans metod Westergren ile korelasyonun analizinde $\mathrm{R}^{2}$ değerleri sırasıyla 0,86 (\%95 $\mathrm{Cl} 0,801$ to 0,913 ) ve 0,978 (\%95 $\mathrm{Cl} 0,967$ to 0,985 ) iken iki cihazın birbiri ile korelasyon analizinde $\mathrm{R}^{2}$ değeri 0,898 (\%95 0,846 to 0,933) bulundu. Passing- Bablok analizinde ise cihazların referans yöntem ile regresyon analizinde Test- 1 cihazı için intercept-0,5 (\%95 Cl -2,42- 0) slope 1,09 (\%95 Cl 1-1,21) ( $y=-0,5+1,09 x)$, otomatik Westergren cihazı için intercept $-0,25$ (\%95 Cl-1,26-0) slope 1,03 (\%95 Cl1-1,08) ( $y=0,25+1,03 x)$ her iki sistemin birbiri ile karşılaştırmasında ise intercept-0,14 (\%95 Cl-1,01-0) slope 1,02 (\%95 Cl 1-1,17) (y=-0,14+1,02x) bulunmuştur. Student $t$ testi ile karşılaştırma yapıldığında, test sonuçlarında gruplar arası anlamlı bir farklılık izlenmedi ( $p>0,05)$.

Sonuç: ESR ölçümü için Test-1 method ve otomatize westergren metod cihazları referans yöntemle karşılaştırıldığında rutin laboratuvarda güvenle kullanılabilirler. Test-1 cihazında yüksek ESR değerlerinde referans yönteme göre sapmalar olduğu izlenmiş ve bu değerlerde dikkatli olunması gerektiği bu konuyla ilgili olarak daha fazla hasta sayısıyla kapsamlı çalışmalara ihtiyaç olduğunu düşünmekteyiz.

Anahtar Sözcükler: Eritrosit Sedimentasyon Hızı, Referans Westergren Metod, Test-1 Metod

Geliş Tarihi: 04.03.2014

Kabul Tarihi: 11.04.2014 


\section{INTRODUCTION}

Erythrocyte Sedimentation Rate (ESR) is most widely used in clinical medicine all over the world. ESR is the measurement of the sedimentation distances of erythrocytes (in anticoagulated blood) with the effect of the gravity in a certain time, in millimeters $(\mathrm{mm})$. ESR is an acute phase reactant that increases in cases of acute or chronic inflammation, infection, tissue damage or necrosis, autoimmune diseases, and malignancy (1). Also in bacterial infection, giant cell arthritis, polymyalgia rheumatica, systemic lupus erythematosus (SLE), vasculitis, lymphoma, multiple myeloma, and metastatic cancer cases, ESR levels range above $100 \mathrm{~mm} /$ hour (2). Although ESR is a commonly used, old and simple test; high ESR is not diagnostic for a certain disease, and low ESR cannot eliminate the inflammation as well $(3,4)$.

The method was described as ESR method in 1921 initially, by $\mathrm{Dr}$. R Fahraeus and Dr. A Westergren (1). International Council for Standardization in Hematology (ICSH) society one of the members of which was Dr. A Westergren, published Westergren method guideline as a reference method for ESR in 1973. While this guideline is revised for several times by ICSH, recently (2010) the relevant guideline of Clinical and Laboratory Standards Institute (CLSI) was revised (1). According to the guideline, anticoagulated blood sample for ESR measurement in Westergren method is made with the colorless glass or plastic pipette or tubes that have minimum $200 \mathrm{~mm}$ scale and have at least $2.55 \mathrm{~mm}$ inner diameter $(1,5,6)$. One and two hours later, ESR sedimentation distance is measured in $\mathrm{mm}$.

In recent years several new techniques which use different method and sample type for measuring ESR have been developed with the following conditions and purposes; the requirement of automatized and close systems for the security of laboratory operators, the request to be able to give results in shorter time, opportunity for being able to study with one type of sample in several systems, and to decrease the amount of blood sample that is taken from patient $(7,8)$. One of these systems is Test- 1 device which studies with photometric method and uses samples with EDTA; and, the other device studies with citrated sample in concordance with automatic Westergren method.

In this study we aimed to compare the devices which are present in our hospital and studied automatic Westergren method and Test-1 method by using reference Westergren method.

\section{MATERIALS AND METHODS}

\section{Subjects}

Randomly selected 80 outpatiens (18 men, 62 women) who were between 20 and 70 years old came to our laboratory with ESR test along with whole blood count request and were included in our study. Hematocrit values of patients were studied with whole blood count device (Advia Centaur 2120, Siemens, Munich, Germany) and who have hematocrit values between $39 \%$ and $44 \%$ were included in this study. For ESR and whole blood count $3 \mathrm{~mL}$ blood sample was taken into tubes with EDTA (K2E $5.4 \mathrm{mg}, \mathrm{BD}$ Vacutainer, Plymouth, UK) and $1.6 \mathrm{~mL}$ blood sample was taken into citrated tubes (0.13M NaSitrat, Vacuplus, Anhui, China) on 7 separate days, which arrived at our laboratory in 2 hours. Samples with EDTA were studied in Test1 device (Alifax, Test-1-THL, Padova, Italy), whereas citrated samples were studied in automatized Westergren device (Eventus VacuPlus ESR 100, Ankara, Turkey) and with reference Westergren method.

Reference method Westergren: The citrated blood was mixed manually. Samples were placed into the sedimentation measurement stand (Eventus VacuPlus, Ankara, Turkey) which has $200 \mathrm{~mm}$ scale. One hour later, ESR was measured in $\mathrm{mm}$.

Test-1 method: Blood samples with EDTA were studied in Test-1 device according to the instruction. The blood samples were mixed slowly for 120 seconds then $150 \mu \mathrm{L}$ blood samples were transferred to the capillaries that are kept at $37^{\circ} \mathrm{C}$. Aggregation and sedimentation capacity of erythrocytes were measured photometrically at $950 \mathrm{~nm}$ wavelength (9).

Automatic Westergren method: First, citrated samples were mixed manually then the tubes were placed in the device. This device kept samples at a $18^{\circ} \mathrm{C}$ stable temperature, and the reading was made in 30 minutes with Infrared method.
In statistical analysis Test-1 and Infrared automatic Westergren method were compared with each other and with reference Westergren method by using concordance correlation coefficient and Passing-Bablok regression analysis (10). Difference between dependent groups was examined with a Student t-test.

\section{RESULTS}

ESR results obtained from the patients were between $1-78 \mathrm{~mm} /$ hour and the data of the studied groups were shown in Table $1 . R^{2}$ values in the correlation of reference Westergren method with Test-1 and automatic Westergren devices were found as $0,86(\% 95 \mathrm{Cl}, 0,801-0,913)$ and 0,978 (\%95 $\mathrm{Cl} 0,967-0,985)$, respectively. The correlation between two devices were 0,898 (\%95 $\mathrm{Cl}$ 0,846-0,933). Graphics that were obtained from concordance correlation coefficient between ESR results that were obtained from Test- 1 device, automatic Westergren device and reference Westergren method were shown in Figure 1. $(A, B, C)$.

With the Passing Bablok analysis, in the regression analysis of devices with reference method, intercept for Test-1 device was found as $-0.5(\% 95 \mathrm{Cl}$ -2.42- 0) and the slope was 1.09 (\%95 Cl 1-1.21) ( $y=-0.5+1.09 x)$. Intercept for automatic Westergren device was found as -0.25 (\%95 Cl -1.26-0) and the slope was 1.03 (\%95 Cl 1-1.08) ( $y=0.25+1.03 x)$. For comparison of these two systems, the intercept was found as -0.14 (\%95 Cl-1.01-0) and the slope was 1.02 (\%95 Cl 1-1.17) $(y=-0.14+1.02 x)$. Between the three methods that we compared, no significant bias was found. Regression analysis graphics were shown in Figure 2. (A,B-C,D-E-F). With a Student t-test, statistically significant difference was not observed in ESR results between the groups $(P>0.05)$.

Table1. Patients ESR results that were studied with three methods

\begin{tabular}{lcc}
\hline & $\begin{array}{l}\text { Mean } \\
\text { \StandartDeviation (SD) }\end{array}$ & $\mathbf{p}$ \\
\hline Westergren ESR (mm/Hour) & $18.625 \pm 16.35$ & $>0.05$ \\
& $19.375 \pm 16.18$ & $>0.05$ \\
Test-1 ESR (mm/Hour) & $19.15 \pm 17.48$ & $>0.05$ \\
$\begin{array}{l}\text { Automic Westergren } \\
\text { (mm/Hour) }\end{array}$ & & \\
\hline
\end{tabular}

Note: $P<0.05$ is accepted as significant statistically.
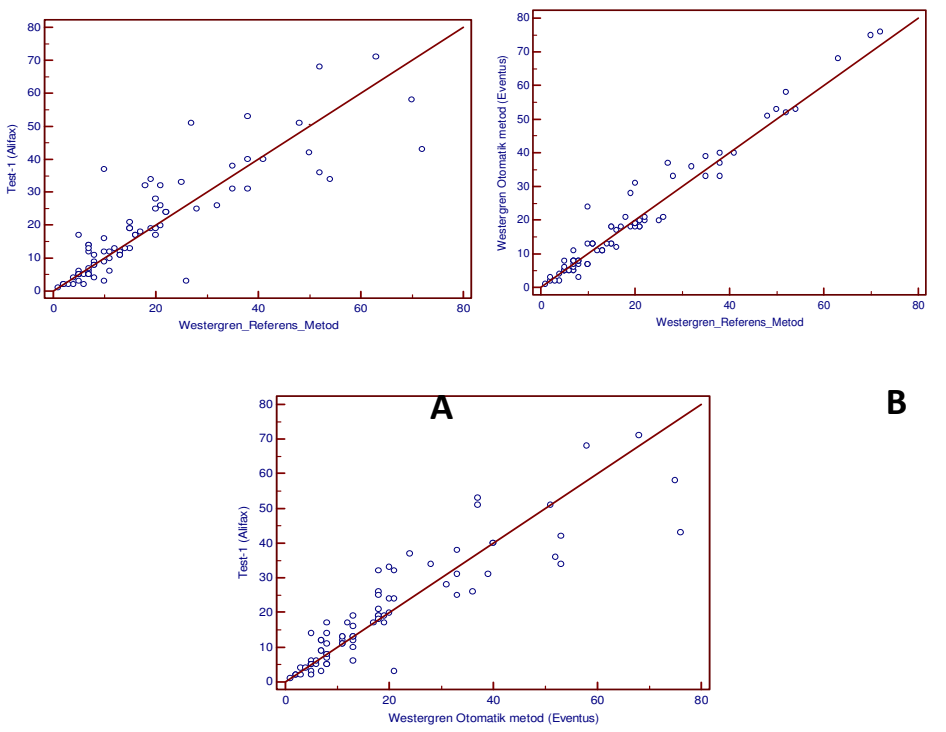

B

Figure 1.Concordant correlation coefficient graphs of both metho@s. (A) Correlation between Test- 1 and reference method westergren (B) Correlation between automatic Westergren method and reference method westergren (C) Correlation between Test-1 and automatic Westergren method 


\section{DISCUSSION}

ESR is a simple and easily applicable test which is commonly used all over the world in the diagnosis and follow-up of inflammatory diseases, infection, autoimmune diseases and malignancy $(1,4)$. Although this test has high sensitivity, its specificity is quite low (11). ICSH suggests that Westergren method as a reference method in ESR, new devices that generate fast, and reliable results which use different methods from reference method have been developed.
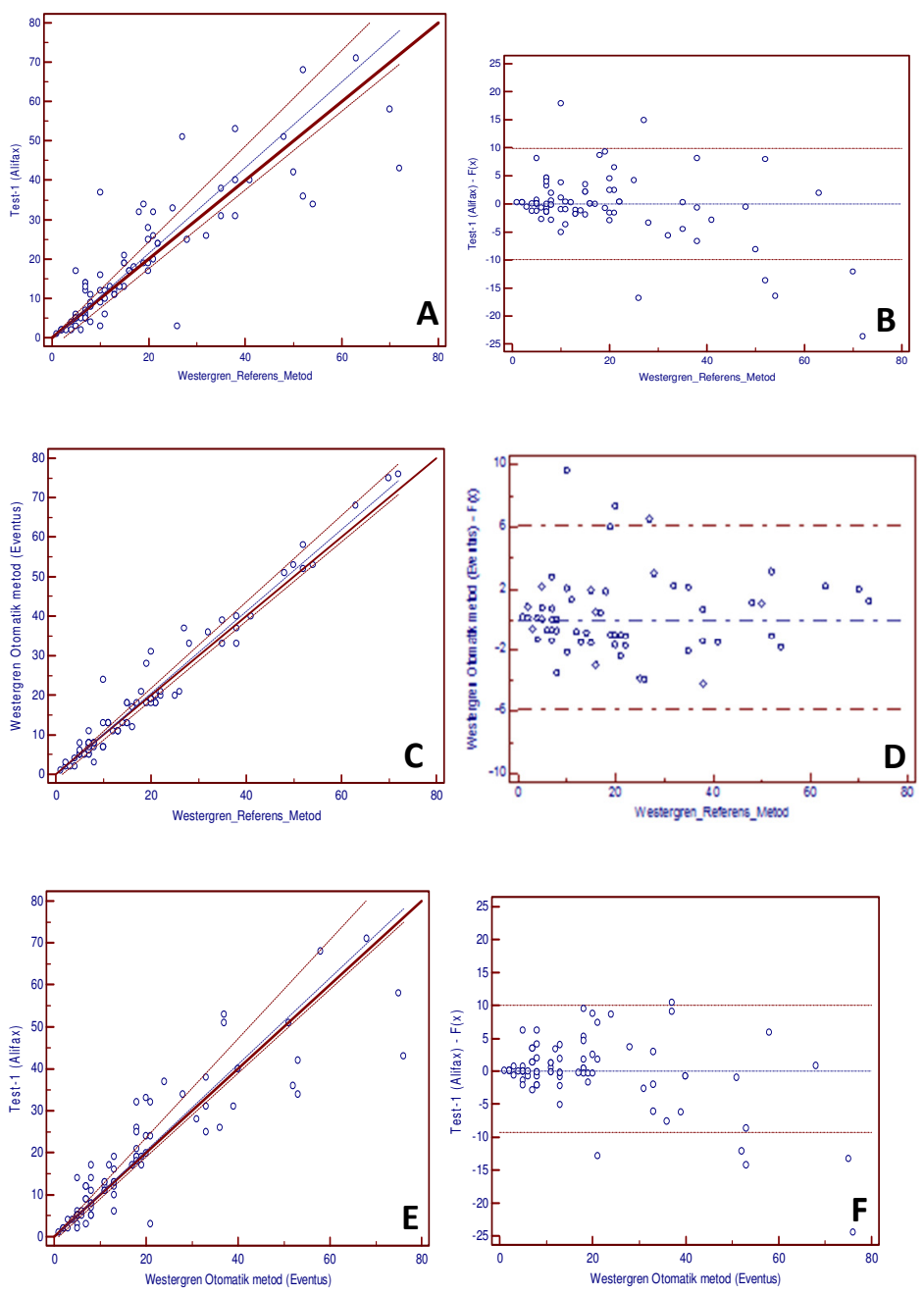

Figure 2. Passing Bablok regression analysis of both methods (A-B) Regression graphs of Test-1 and reference method westergren (C-D) Regression graphs of Automatic Westergren and reference method Westergren (E-F) Regression graphs of Test-1 and Automatic Westergren method.

In our study, with the comparison of Test-1 and reference method Westergren ESR results, we found a significant correlation between the methods. The significant correlation which belong to the two methods that Plebani et al. (5) found was in line with that of our study, as well. Also other studies in the literature support our results $(11,12,13)$. We consider that Test-1 analyzer will be appropriate for routine laboratory use; because Test-1 gives results in a shorter period of time (2-3 min.), is simple and more secure for operators. Blood samples that are taken into the tubes with EDTA can be used for measuring ESR and for performing other hematologic tests at the same time, so the sample amount requirement is relatively small (9). Both of the methods have no significant bias inside the acceptable limits statistically. Test- 1 has the lowest $R^{2}$ value and showed deviation at higher ESR values $(\geq 40 \mathrm{~mm} / \mathrm{saat}(\mathrm{n}=8))$. At high ESR values Hardeman et al.(14) also found deviations that are similar to our results. To evaluate the deviation in these ESR values, we think that studies with more patients are required since the size of our data was small.
In the comparison of ESR results that are obtained with automatic Westergren device with the reference method a significant correlation was detected. The correlation coefficient of automized Westergren device with the reference Westergren method was higher than that of the Test- 1 device correlation with the reference westergren method. Our results were compatible with those of other studies in the literature $(6,13,15)$. While accurate and reliable results are obtained in studies that are performed with automatic Westergren device, shortening of reading time is also the advantage of the system. However, the use of citrated tubes only in this system requires additional sample from the patient be taken.

\section{CONCLUSION}

Test-1 method and automated Westergren method devices can be used reliably in the ESR measurement in routine laboratory when compared with the reference Westergren method. In routine laboratory use, sample collection and handling cost would be reduced with EDTA tubes. Using device is safe for operators and short reading time is another advantage of the Test1 method. We suggest that the evaluation of results of high sedimentation values be made carefully and for high ESR values more comprehensive future studies be conducted.

\section{Conflict of Interest}

No conflict of interest was declared by the authors.

\section{REFERENCES}

1. Jou JM, Lewis SM, Briggs $C$, Lee $S H$, De La Salle $B$, McFadden $S$. International Council for Standardization in Haematology. ICSH review of the measurement of the erythocyte sedimentation rate. Int J Lab Hematol 2011;33:125-32.

2. Brigden ML. Clinical utility of the erythrocyte sedimentation rate. Am Fam Physician 1999;60:1443-50.

3. Samir P Desai. Clinician's Guide to Laboratory Medicine. $3^{\text {rd }}$ edition.2004. Part VIII: Rheumatology.

4. Bochen K, Krasowka A, Milaniuk S, Kulczyńska M, Prystupa A, Dzida G. Erytrocyte sedimentation rate an old marker with new applications. Journal of Pre-clinical and Clinical Research 2011;5:50-5

5. Keopke J. Welcome innovation in erythrocyte sedimentation testing. Am J Clin Pathol 2002;118:11-2

6. ICSH recommendations for measurement of erythrocyte sedimentation rate. International Council for Standardization in Haematology (Expert Panel on Blood Rheology) J Clin Pathol 1993;46:198-203.

7. Plebani M, Piva E. Erythrocyte sedimentation rate: use of fresh blood for quality control. Am J Clin Pathol 2002;117:621-6.

8. Atas A, Cakmak A, Soran M, Karazeybek H. Comparative study between the Ves-matic and microerythrocyte sedimentation rate method. J Clin Lab Anal 2008;22:70-2

9. Plebani M, De Toni S, Sanzari MC, Bernard D, Stockrelter E. The TEST 1 automated system: a new method for measuring the erythrocyte sedimentation rate. Am J Clin Pathol 1998;110;334-40

10. Passing $\mathrm{H}$, Bablok $\mathrm{W}$. A new biometrical procedure for testing the equality of measurements from two different analytical methods. Application of lineer regression procedures for method comparison studies in clinical chemistry. Part I. J Clin Chem Clin Biochem 1983;21:709-20

11. Aktaş $M$, Erçetin N, Çimen B, Kanık A, Eskandari G, Atik U. Westergren metodu ve Test-1 Cihazı ile Ölçülen Eritrosit Sedimentasyon Hızı Sonuçlarının Karşılaştırılması. Türk Klinik Biyokimya Dergisi 2004;2:29-33

12. Arıkan S, Akalın N. Comparison of the erythrocyte sedimentation rate measured by the Micro Test 1 sedimentation analyzer and the conventional Westergren method. Ann Saudi Med 2007;27:362-5.

13. Malin R, Wirta V, Hiltunen PT, Lehtimaki T. Erythrocyte Sedimentation Rate by the Test-1 Analyzer. Clinical Chemistry 2000:46:882-3.

14. Hardeman MR, Levitus M, Pelliccia A, Bouman AA. Test 1 analyser for determination of ESR. 1. Practical evaluation and comparison with the Westergren technique. Scand J Clin Lab Invest 2010;70:21-5.

15. Happe MR, Battafarano DF, Dooley DP, Rennie TA, Murphy FT, Casey TJ et al. Validation of the Diesse Mini-Ves erythrocyte sedimentation rate (ESR) analyzer using the Westergren ESR method in patients with systemic inflammatory conditions. Am J Clin Pathol 2002;118:14-7. 